\title{
Effects of breed and casein genetic variants on protein profile in milk from Swedish Red, Danish Holstein, and Danish Jersey cows
}

\author{
F. Gustavsson, ${ }^{* 1}$ A. J. Buitenhuis, $†$ M. Johansson, $\ddagger$ H. P. Bertelsen, $\dagger$ M. Glantz, ${ }^{*}$ N. A. Poulsen, $\S$ \\ H. Lindmark Månsson, „\# H. Stålhammar,II L. B. Larsen,§ C. Bendixen,† M. Paulsson, ${ }^{\star}$ and A. Andrén¥ \\ *Department of Food Technology, Engineering and Nutrition, Lund University, PO Box 124, SE-221 00 Lund, Sweden \\ †Department of Molecular Biology and Genetics, Aarhus University, Blichers Allé 20, PO Box 50, DK-8830 Tjele, Denmark \\ †Department of Food Science, BioCenter, Swedish University of Agricultural Sciences, PO Box 7051, SE-750 07 Uppsala, Sweden \\ $\S$ Department of Food Science, Aarhus University, Blichers Allé 20, PO Box 50, DK-8830 Tjele, Denmark \\ \#LRF Dairy Sweden, Ideon Science Park, SE-223 70 Lund, Sweden \\ IVVikingGenetics, PO Box 64, SE-532 21 Skara, Sweden
}

\begin{abstract}
In selecting cows for higher milk yields and milk quality, it is important to understand how these traits are affected by the bovine genome. The major milk proteins exhibit genetic polymorphism and these genetic variants can serve as markers for milk composition, milk production traits, and technological properties of milk. The aim of this study was to investigate the relationships between casein $(\mathrm{CN})$ genetic variants and detailed protein composition in Swedish and Danish dairy milk. Milk and DNA samples were collected from approximately 400 individual cows each of 3 Scandinavian dairy breeds: Swedish Red (SR), Danish Holstein (DH), and Danish Jersey (DJ). The protein profile with relative concentrations of $\alpha$-lactalbumin, $\beta$-lactoglobulin, and $\alpha_{\mathrm{S1}^{-}}, \alpha_{\mathrm{S2}^{-}}, \kappa^{-}$, and $\beta$-CN was determined for each milk sample using capillary zone electrophoresis. The genetic variants of the $\alpha_{\mathrm{S1}^{-}}(C S N 1 S 1), \beta-(C S N 2)$, and k-CN (CSN3) genes for each cow were determined using TaqMan SNP genotyping assays (Applied Biosystems, Foster City, CA). Univariate statistical models were used to evaluate the effects of composite genetic variants, $\alpha_{S 1}-\beta-\kappa-C N$, on the protein profile. The 3 studied Scandinavian breeds differed from each other regarding CN genotypes, with DH and SR having similar genotype frequencies, whereas the genotype frequencies in DJ differed from the other 2 breeds. The similarities in genotype frequencies of SR and $\mathrm{DH}$ and differences compared with DJ were also seen in milk production traits, gross milk composition, and protein profile. Frequencies of the most common composite $\alpha_{S 1}-\beta-\kappa-C N$ genotype $\mathrm{BB} / \mathrm{A}^{2} \mathrm{~A}^{2} / \mathrm{AA}$ were $30 \%$ in $\mathrm{DH}$ and $15 \%$ in $\mathrm{SR}$, and cows that had this genotype gave milk with lower relative concentrations of $\kappa-$ and $\beta-\mathrm{CN}$ and higher
\end{abstract}

Received July 29, 2013.

Accepted February 13, 2014.

${ }^{1}$ Corresponding author: Frida.Gustavsson@food.lth.se relative concentrations of $\alpha_{S^{-}} \mathrm{CN}$, than the majority of the other composite genotypes in SR and DH. The effect of composite genotypes on relative concentrations of the milk proteins was not as pronounced in DJ. The present work suggests that a higher frequency of $\mathrm{BB} /$ $\mathrm{A}^{1} \mathrm{~A}^{2} / \mathrm{AB}$, together with a decrease in $\mathrm{BB} / \mathrm{A}^{2} \mathrm{~A}^{2} / \mathrm{AA}$, could have positive effects on DH and SR milk regarding, for example, the processing of cheese.

Key words: milk protein composition, casein, genetic polymorphism, composite genotype

\section{INTRODUCTION}

Milk composition affects both the processing of milk and its nutritional value. It is well known that variation in milk composition is influenced by environmental factors such as feeding, the physiological condition of the cow, and the genetic makeup (Walstra et al., 2006). Differences also exist in milk composition between breeds and individual cows within a breed, which are partly due to genetic variation (e.g., McLean et al., 1984; Wedholm et al., 2006; Poulsen et al., 2012). The detailed protein composition is important for the processability and functionality of different dairy products, such as yogurt, milk powder, and cheese (Walstra et al., 2006). As detailed milk protein composition is not included in the Swedish and Danish national milk recording systems (Swedish Dairy Association, 2011; RYK, 2012), knowledge of how the detailed protein composition varies between and within the Scandinavian breeds is limited. The milk proteins are subdivided into caseins and whey proteins. The caseins $\alpha_{\mathrm{S1}^{-}}, \alpha_{\mathrm{S}^{-}}, \beta-$, and $\kappa-\mathrm{CN}$, represent approximately $80 \%$ of total milk protein, whereas the other $20 \%$ consists of whey proteins, mainly $\beta$-LG and $\alpha$-LA (Farrell et al., 2004). For decades, it has been known that the major milk proteins are present in different genetic variants in milk. Extensive research has shown that these genetic variants can serve as markers for both milk yield and composition and, consequently, 
milk processability (e.g., Ikonen et al., 1997; Hallén et al., 2007; Bonfatti et al., 2010a). Some of these studies have shown that genetic protein variants affect absolute concentrations (McLean et al., 1984; Ikonen et al., 1997; Hallén et al., 2008) and relative concentrations (Bobe et al., 1999; Heck et al., 2009a; Bonfatti et al., 2010b) of the individual milk proteins, especially k-CN genetic variant $\mathrm{B}$, which has been shown to have a positive effect on $\kappa$-CN concentration (Bobe et al., 1999; Hallén et al., 2008; Heck et al., 2009a).

As no large-scale study has been performed on detailed protein composition in the most common dairy cow breeds in Sweden and Denmark, milk was collected from about 400 each of Swedish Red (SR; $41 \%$ of the Swedish cattle population), Danish Holstein (DH; $71 \%$ of the Danish cattle population), and Danish Jersey (DJ; $13 \%$ of the Danish cattle population) breeds. The aim of this study was to investigate the relationship between casein genetic variants and detailed protein composition in Swedish and Danish milk. Both the knowledge of how detailed milk composition varies between breeds and how it varies between composite $\alpha_{S 1}-\beta-\kappa-C N$ genotypes within a breed could help to direct and improve the quality of milk used for further processing. This could be done using organized breeding programs or by using milk from different breeds for the production of different dairy products.

\section{MATERIALS AND METHODS}

\section{Milk Samples}

Morning milk samples and tissue/blood samples were collected from the following cows: $415 \mathrm{DH}$ (20 dairy herds, collected between October and December 2009), 406 DJ (22 dairy herds, between February and April 2010), and 392 SR (20 dairy herds, between April and May 2010 and September 2010 and April 2011). The cows were selected to be as unrelated as possible using recorded ancestry and, in most cases, only 1 daughter was chosen per sire and farm. The majority of the cows were in lactations 1 to 3 and in DIM 70 to 245. In SR, $1 \%$ of the animals were in lactation 4 and 5 and $25 \%$ of the animals were milked before lactation d 70 or after lactation d 245, respectively. Milk yield was recorded at time of sampling and the daily milk yield was estimated from milk yield at each milking and how many times the cows were milked per day and farm. Fresh milk samples were analyzed for contents of total protein, total casein, and fat using the infrared technique (MilkoScan FT2; Foss Analytical A/S, Hillerød, Denmark). This method has previously been validated for casein measurements (Sørensen et al., 2003). Somatic cell counts were measured by flow cytometry. The DJ and DH samples were measured using a Fossomatic 5000 somatic cell counter (Foss Analytical A/S) at a Danish certified dairy analysis laboratory (Eurofins Steins Laboratorium A/S, Holstebro, Denmark). The SR samples were measured using a CombiFoss 5000 analyzer (Foss Analytical A/S) at a certified Swedish dairy analysis laboratory (Eurofins Steins Laboratorium AB, Jönköping, Sweden). All samples had SCC below 500,000 cells/mL.

\section{Sample and Capillary Zone Electrophoresis Buffer Preparation}

At the day of sampling, the collected milk samples were defatted by centrifugation (SR samples at 2,000 $\times g$ and DH and DJ samples at 2,643 $\times g$ ) for $30 \mathrm{~min}$ at $4^{\circ} \mathrm{C}$, with subsequent removal of the fat layer. Skim milk samples were frozen and stored at $-20^{\circ} \mathrm{C}$ until the day of analysis. The samples and capillary electrophoresis buffers were prepared according to Åkerstedt et al. (2012). In short, the sample solution was prepared by mixing $300 \mu \mathrm{L}$ of milk with $700 \mu \mathrm{L}$ of sample buffer and, after mixing, the sample solution was left at room temperature for $1 \mathrm{~h}$. In the sample buffer, M-D,Ldithiothreitol (DTT; Sigma, Stockholm, Sweden) was used as reducing agent. The sample solutions were filtered through a $0.45-\mu \mathrm{m}$ nylon membrane filter before analyses by capillary zone electrophoresis (CZE).

\section{CZE Analysis}

Milk analyses were carried out with CZE according to Åkerstedt et al. (2012). The CZE equipment (G1600AX; Agilent Technologies Sweden AB, Kista, Sweden) was controlled by ChemStation software (version A 10.02; Agilent Technologies Sweden AB). In summary, milk protein separations were performed using an unfused silica standard capillary with a $50-\mu \mathrm{m}$ i.d., 40-cm active length (ChromTech AB, Märsta, Sweden), and separations were carried out at $45^{\circ} \mathrm{C}$ at a constant voltage of $25 \mathrm{kV}$. Sample solutions were injected at the anode by pressure injection at $5 \mathrm{kPa}$ for $7 \mathrm{~s}$.

\section{Identification of Peaks and Quantification of the Individual Milk Proteins}

Milk protein standards of $\alpha_{S^{-}} \mathrm{CN}, \beta-\mathrm{CN}, \kappa-\mathrm{CN}, \alpha-\mathrm{LA}$, and $\beta-\mathrm{LG}$ (Sigma) were used for peak identification. Furthermore, the peak identifications were confirmed by a comparison with previously published electropherograms (Otte et al., 1997; Miralles et al., 2003; Heck et al., 2008). Multiple peaks found around the main peak of $\alpha_{\mathrm{S}_{2}} \mathrm{CN}$ were interpreted as $\alpha_{\mathrm{S} 2^{-}} \mathrm{CN}$ isoforms according to Heck et al. (2008). The relative concentration of $\alpha_{S_{1}}-\mathrm{CN}$ was divided into $\alpha_{\mathrm{S}^{-}} \mathrm{CN} 8 \mathrm{P}, \alpha_{\mathrm{S} 1}-\mathrm{CN}$ 
$9 \mathrm{P}$, and total $\alpha_{\mathrm{S}^{-}} \mathrm{CN}$. Total $\alpha_{\mathrm{S}^{-}} \mathrm{CN}$ is the sum of relative concentrations of $\alpha_{\mathrm{S}_{1}}-\mathrm{CN} 8 \mathrm{P}$ and $\alpha_{\mathrm{S}_{1}-\mathrm{CN}} 9 \mathrm{P}$ and also the peak migrating just before the $8 \mathrm{P}$ peak, all according to Heck et al. (2008). As $\kappa-\mathrm{CN}$ is present in different phosphorylated and glycosylated forms, it separates into multiple peaks, with the monophosphorylated form in the highest concentration (Otte et al., 1997; Miralles et al., 2001). The different genetic variants of $\beta-\mathrm{CN}$ can be distinguished using $\mathrm{CZE}$, where $\beta-\mathrm{CN} \mathrm{B}$ separates first, followed by $\mathrm{A}^{1}, \mathrm{~A}^{2} / \mathrm{I}$ (which cannot be distinguished from each other because of similar migration times), and $\mathrm{A}^{3}$ (Recio et al., 1997). Depending on $\beta-\mathrm{CN}$ genotype, some $\kappa-\mathrm{CN}$ isoforms will be visible, whereas other will comigrate with $\beta$-CN. In the electropherograms where a $\kappa-\mathrm{CN}$ peak was visible because of the absence of a genetic protein variant of $\beta-\mathrm{CN}$, the relative concentration was determined for that peak. The average of these relative concentrations was then subtracted from and added to the relative concentrations of $\beta-\mathrm{CN}$ and $\kappa-\mathrm{CN}$, respectively, in electropherograms where the $\mathrm{k}-\mathrm{CN}$ peak was hidden. The monophosphorylated form of $\kappa-\mathrm{CN}$ was assigned $\kappa-\mathrm{CN}$ $1 \mathrm{P}$ and the estimated relative concentration of total $\kappa-\mathrm{CN}$ was assigned adjusted total $\kappa-\mathrm{CN}$. The estimated relative concentration of $\beta-\mathrm{CN}$ was assigned adjusted total $\beta$-CN. Hence, $\beta$-CN was the relative concentration of $\beta-\mathrm{CN}$ and the comigrated $\kappa-\mathrm{CN}$, all according to Heck et al. (2008). As this was an assumption, both the adjusted and unadjusted values were included in the analyses. The relative concentrations of the individual milk proteins were estimated the same way as by Heck et al. (2008). Equation [1] was used to estimate the relative concentration of an individual protein:

$$
C_{x}=\frac{A_{x} / t_{x}}{\sum_{i=1}^{n}\left(A_{i} / t_{i}\right)} \times 100 \%,
$$

where $C_{x}$ is the relative concentration, $A_{x}$ is the specific area of interest in the electropherogram, $t_{x}$ is the migration time in minutes of protein $x, i$ is the index of summation, and $n$ is the total number of peaks that together form $100 \%$ of the area.

Some of the electropherograms showed inadequate separation of whey proteins and, therefore, several protein profiles were excluded from the analysis. The inadequate separation was thought to be due to insufficient fat removal, as traces of milk fat can alter the migration behavior of the proteins in CZE (C. Olieman, NIZO Food Research BV, Ede, the Netherlands, personal communication). After disregarding samples with inadequate separation of whey proteins, $381 \mathrm{DH}, 221$ DJ, and 325 SR (protein profile sample set) were included in the protein profile analysis.

\section{Genotyping of Genetic Variants}

Blood samples (SR) and ear tissue samples (DH and DJ) were used to extract DNA according to Poulsen et al. (2013). The extracted genomic DNA from all animals was genotyped for $\alpha_{S_{1}}(C S N 1 S 1), \beta-(C S N 2)$, and $\kappa-\mathrm{CN}$ (CSN3) genetic variants using TaqMan SNP genotyping assays (Applied Biosystems, Foster City, CA), using the primer sequence according to Poulsen et al. (2013). The assays distinguished between CSNS1 variants $\mathrm{A}, \mathrm{B}, \mathrm{C}, \mathrm{D}$, and $\mathrm{F}$; CSN2 variants $\mathrm{A}^{1}, \mathrm{~A}^{2}, \mathrm{~A}^{3}$, $\mathrm{B}$, and $\mathrm{I}$; and $C S N 3$ variants $\mathrm{A}, \mathrm{B}$, and $\mathrm{E}$, which are reported to be the most common casein variants (Farrell et al., 2004). Both the present study and the study by Poulsen et al. (2013) is part of the Swedish-Danish milk genomics initiative where the same samples have been used in several studies with different analyses. However, the present study differs from Poulsen et al. (2013) regarding the number of cows included in the analyses.

\section{Statistical Analysis}

One-way ANOVA was used to determine differences in milk composition and milk production traits between breeds using the full sample set (Minitab version 14; Minitab Ltd., Coventry, UK). The protein profile was compared between breeds in the protein profile subset.

The effect of each of the composite $\alpha_{\mathrm{S}_{1}} \beta-\kappa-\mathrm{CN}$ genotypes on relative concentrations of the different milk proteins was estimated within each breed using a linear mixed model approach in DMU software (Madsen and Jensen, 2007).

For DH, the model was as follows:

$$
\begin{gathered}
\mathrm{Y}_{\mathrm{ijk}}=\mu+\operatorname{herd}_{\mathrm{i}}+\text { parity }_{\mathrm{j}}+\mathrm{DIM}+\text { compgen }_{2} \\
+ \text { compgen }_{3}+\operatorname{compgen}_{4}+\operatorname{compgen}_{5} \\
+\operatorname{compgen}_{6}+\operatorname{compgen}_{7}+\mathrm{A}_{\mathrm{k}}+\mathrm{e}_{\mathrm{ijk}} .
\end{gathered}
$$

For DJ, the model was as follows:

$$
\begin{gathered}
\mathrm{Y}_{\mathrm{ijk}}=\mu+\text { herd }_{\mathrm{i}}+\text { parity }_{\mathrm{j}}+\mathrm{DIM}+\text { compgen }_{2} \\
+ \text { compgen }_{3}+\text { compgen }_{4}+\text { compgen }_{5} \\
+ \text { compgen }_{6}+\text { compgen }_{7}+\text { compgen }_{8} \\
\quad+\operatorname{compgen}_{9}+\mathrm{A}_{\mathrm{k}}+\mathrm{e}_{\mathrm{ijk}} .
\end{gathered}
$$

For SR, the model was as follows:

$$
\begin{gathered}
\mathrm{Y}_{\mathrm{ijk}}=\mu+\operatorname{herd}_{\mathrm{i}}+\text { parity }_{\mathrm{j}}+\mathrm{DIM}+\text { compgen }_{2} \\
+ \text { compgen }_{3}+\text { compgen }_{4}+\text { compgen }_{5} \\
+\operatorname{compgen}_{6}+\operatorname{compgen}_{7}+\operatorname{compgen}_{8} \\
+\operatorname{compgen}_{9}+\mathrm{A}_{\mathrm{k}}+\mathrm{e}_{\mathrm{ijk}} .
\end{gathered}
$$


The results of models [2] to [4] were compared with model [5]:

$$
\mathrm{Y}_{\mathrm{ijk}}=\mu+\operatorname{herd}_{\mathrm{i}}+\text { parity }_{\mathrm{j}}+\mathrm{DIM}+\mathrm{A}_{\mathrm{k}}+\mathrm{e}_{\mathrm{ijk}}
$$

for each breed separately, where $Y_{\mathrm{ijk}}$ is the phenotype of the kth individual in herd $\mathrm{i}$ and parity $\mathrm{j} ; \mu$ is the overall mean of the trait; herd is a fixed effect $(\mathrm{i}=1$, $2, \ldots, 22)$; parity is a fixed effect $(\mathrm{j}=1,2,3$, or 4$)$, DIM is a covariate of DIM (d 129 to 229 in DH, d 130 to 252 in DJ, and d 18 to 427 in SR), compgen is a vector of 0 and 1 fitted as a covariate, indicating the composite $\alpha_{\mathrm{S} 1}-\beta-\kappa-\mathrm{CN}$ genotype of an animal; $\mathrm{A}_{\mathrm{k}}$ is the random additive genetic effect of animal $\mathrm{k}$; and $\mathrm{e}_{\mathrm{ijk}}$ is the random residual effect. In Equations [2] and [3], compgen $_{1}$ is the composite genotype $\mathrm{BB} / \mathrm{A}^{2} \mathrm{~A}^{2} / \mathrm{AA}$, which is the most common one in $\mathrm{DH}$ and the third most common in SR. In Equation [4], compgen $_{1}$ is the most common DJ composite genotype, $\mathrm{BC} / \mathrm{A}^{2} \mathrm{~A}^{2} / \mathrm{AB}$; compgen $_{2-9}$ are the other composite genotypes present at a higher frequency than $2.5 \%$, both in the full sample set and in the protein profile sample set, in each breed separately. When disregarding animals with composite genotypes present at lower frequencies than $2.5 \%$, the models estimating the effects of composite genotypes on protein profile included $309 \mathrm{DH}, 309 \mathrm{SR}$, and $199 \mathrm{DJ}$ (protein profile subset). Relationships between animals were accounted for and the pedigrees were traced back for 5 generations for each breed separately. The DH pedigree consisted of 4,811 animals, the DJ pedigree consisted of 4,351 animals, and the SR pedigree consisted of 4,636 animals. The genetic variance explained by the composite genotypes was calculated as

$\sum\left[\mathrm{fr} \times(1-\mathrm{fr}) \times(\text { effect of the composite genotype })^{2} /\left(\sigma_{\mathrm{G}}^{2}+\sigma_{\mathrm{e}}^{2}\right) \times 100\right]$,

where fr is the frequency of the composite genotype, $\sigma_{\mathrm{G}}^{2}$ is the genetic variance, and $\sigma_{\mathrm{e}}^{2}$ is the residual variance.

\section{RESULTS}

\section{Effect of Breed on Milk Composition, Milk Production Traits, and Protein Profile}

It was evident that breed affected both milk composition and milk production traits as shown in Table 1. A difference existed in mean SCC between the breeds, with SR giving milk with a lower mean $\operatorname{SCC}(P<$ $0.05)$ than DH and DJ. The DJ cows gave milk with lower milk, protein, and casein yields $(P<0.05)$ and with higher fat, protein, and casein contents than SR and $\mathrm{DH}$, whereas no difference existed in fat yield. Milk from SR cows had higher protein contents than milk from DH cows, whereas no differences existed in fat and casein contents, or in milk, fat, protein, and casein yields. Observations on breed differences in milk composition and milk production traits agree well with data from the national cow databases in Sweden and Denmark (Swedish Dairy Association, 2011; RYK, 2012). Further, the results agree with published studies on individual cows (Wedholm et al., 2006; Frederiksen et al., 2011b). Differences in protein profile could be noticed between milk from the 3 breeds (Table 2). The highest relative concentrations of $\alpha-\mathrm{LA}, \beta-\mathrm{LG}, \alpha_{\mathrm{S1}}-\mathrm{CN}$ 9P, $\beta-\mathrm{CN}$, and adjusted total $\beta-\mathrm{CN}$ were found in $\mathrm{DH}$, whereas the highest relative concentrations of $\alpha_{\mathrm{S}_{2}}-\mathrm{CN}, \alpha_{\mathrm{S} 1}-\mathrm{CN} 8 \mathrm{P}$, total $\alpha_{\mathrm{S}_{1}} \mathrm{CN}$, and $\kappa-\mathrm{CN} 1 \mathrm{P}$ were found in DJ. Milk from DJ and SR had higher relative concentrations of adjusted total $\kappa$-CN than milk from DH.

\section{Genotype Frequencies}

The presence and frequencies of different casein alleles and genotypes were quite similar between $\mathrm{DH}$ and SR, whereas the DJ breed was quite different from the other 2 breeds (Table 3 ). Regarding the $\kappa$-CN genotypes, the DJ cows were distinguished from SR and DH regarding the high occurrence of the $\mathrm{B}$ variant and the absence of the $\mathrm{E}$ variant. In $\mathrm{SR}$ and $\mathrm{DH}$, the $\kappa-\mathrm{CN} \mathrm{A}$ variant was the most common, whereas $\kappa-\mathrm{CN} \mathrm{E}$ was more common in SR than in DH. Five $\beta-\mathrm{CN}$ variants were represented in these 3 breeds (i.e., $\mathrm{A}^{1} . \mathrm{A}^{2}, \mathrm{~A}^{3}$, $\mathrm{B}$, and I). The $\beta-\mathrm{CN} \mathrm{A}^{2}$ variant was the most common variant in all 3 breeds, whereas $\beta-\mathrm{CN} \mathrm{A}^{1}$ was more common in SR than in $\mathrm{DH}$ and DJ. Variant $\beta$-CN B was more common in DJ than in the other 2 breeds and $\beta$-CN I was present in low frequencies in $\mathrm{DH}$ and DJ. Regarding $\alpha_{\mathrm{S}^{-}} \mathrm{CN}$, almost all of the $\mathrm{DH}$ and SR cows were homozygous for the B variant and only a few animals carried the $\mathrm{C}$ variant. In DJ, both $\alpha_{\mathrm{S1}}-\mathrm{CN} B$ and $\mathrm{C}$ variants were present at high frequencies.

As the aim of the present study was to investigate the effect of composite genetic variants on the protein profile, the frequencies of composite $\alpha_{S 1}-\beta-\kappa-C N$ genotypes was presented for the protein profile sample set, which included 381 DH, 221 DJ, and 325 SR (Table 4). The most common composite casein genotype in $\mathrm{DH}$ was $\mathrm{BB} / \mathrm{A}^{2} \mathrm{~A}^{2} / \mathrm{AA}$, which was present at a frequency of $30 \%$. This composite genotype was also quite common in SR at a frequency of $13 \%$, whereas the most common composite genotype in $\mathrm{SR}$ was $\mathrm{BB} / \mathrm{A}^{1} \mathrm{~A}^{2} / \mathrm{AE}$ (18\%). Genotype $\mathrm{BB} / \mathrm{A}^{1} \mathrm{~A}^{2} / \mathrm{AA}$ was the second most common composite genotype in both $\mathrm{DH}$ and SR, with a frequency of 15 and $17 \%$, respectively. The most common composite genotype in $\mathrm{DJ}$ was $\mathrm{BC} / \mathrm{A}^{2} \mathrm{~A}^{2} / \mathrm{AB}$ (23\%), followed by $\mathrm{BC} / \mathrm{BA}^{2} / \mathrm{BB}(19 \%)$ and $\mathrm{CC} / \mathrm{A}^{2} \mathrm{~A}^{2} /$ 
Table 1. Descriptive statistics for lactation data, milk production traits, and milk composition in Danish Holstein (DH), Swedish Red (SR), and Danish Jersey (DJ) cows using the full sample set (415 DH, 392 SR, and 406 DJ)

\begin{tabular}{|c|c|c|c|c|c|c|c|c|c|}
\hline Trait $^{1}$ & \multicolumn{9}{|c|}{ Breed } \\
\hline DIM (d) & $179.0^{\mathrm{a}}$ & 21.3 & 11.9 & $187.0^{\mathrm{b}}$ & 76.8 & 41.1 & $186.1^{\mathrm{ab}}$ & 22.8 & 12.2 \\
\hline Parity & 1.7 & 0.8 & 45.1 & 1.7 & 0.8 & 43.5 & 1.7 & 0.8 & 45.3 \\
\hline $\mathrm{SCC}(\times 1,000 / \mathrm{mL})$ & $110.3^{\mathrm{a}}$ & 109.8 & 99.5 & $54.1^{\mathrm{b}}$ & 64.0 & 118.3 & $113.1^{\mathrm{a}}$ & 108.6 & 96.0 \\
\hline Casein $(\mathrm{g} / 100 \mathrm{~g})$ & $2.7^{\mathrm{a}}$ & 0.1 & 4.5 & $2.7^{\mathrm{a}}$ & 0.1 & 3.4 & $3.0^{\mathrm{b}}$ & 0.2 & 4.8 \\
\hline MY $(\mathrm{kg} / \mathrm{d})$ & $30.7^{\mathrm{a}}$ & 8.1 & 26.5 & $30.2^{\mathrm{a}}$ & 9.9 & 33.0 & $20.5^{\mathrm{b}}$ & 5.2 & 25.1 \\
\hline FY $(\mathrm{kg} / \mathrm{d})$ & 1.2 & 0.4 & 30.1 & 1.2 & 0.4 & 35.2 & 1.2 & 0.3 & 23.7 \\
\hline PY (kg/d) & $1.1^{\mathrm{a}}$ & 0.3 & 25.4 & $1.1^{\mathrm{a}}$ & 0.3 & 29.5 & $0.9^{\mathrm{b}}$ & 0.2 & 23.6 \\
\hline $\mathrm{CY}(\mathrm{kg} / \mathrm{d})$ & $0.8^{\mathrm{a}}$ & 0.2 & 25.9 & $0.8^{\mathrm{a}}$ & 0.3 & 31.7 & $0.6^{\mathrm{b}}$ & 0.2 & 24.2 \\
\hline
\end{tabular}

${ }^{a-c}$ Means within a row with different superscript letters differ significantly $(P<0.05)$.

${ }^{1} \mathrm{MY}=$ milk yield; $\mathrm{FY}=$ fat yield; $\mathrm{PY}=$ protein yield; $\mathrm{CY}=$ casein yield.

$\mathrm{BB}(16 \%)$, whereas the frequency of $\mathrm{BB} / \mathrm{A}^{2} \mathrm{~A}^{2} / \mathrm{AA}$ was much lower in DJ than in SR and DH (4\%).

\section{Effect of Composite Genotypes}

The effects of composite $\alpha_{\mathrm{S} 1}-\kappa-\beta-\mathrm{CN}$ genotypes on milk production traits, gross milk composition, and protein profile were investigated. No effect could be seen on milk production traits in any of the breeds or on gross milk composition in SR (fat, protein, and casein contents; data not shown). Only a few composite genotypes had an effect on gross composition in DH and DJ (data not shown). However, an effect of $\alpha_{\mathrm{S}_{1}} \kappa^{-}-$ $\beta-\mathrm{CN}$ genotypes was detected on the protein profile in all 3 breeds.

Whey Proteins. No significant effects were detected of composite $\alpha_{S 1^{-}} \kappa-\beta-C N$ genotypes on relative concentrations of $\alpha$-LA in either of the breeds (data not shown). Regarding relative concentrations of $\beta-\mathrm{LG}$ in $\mathrm{SR}$ and $\mathrm{DH}$, the composite genetic variant $\mathrm{BB} /$ $\mathrm{A}^{1} \mathrm{~A}^{2} / \mathrm{AB}$ gave milk with a significantly higher relative concentration of $\beta$-LG $(P=0.02-0.09)$ compared with $\mathrm{BB} / \mathrm{A}^{2} \mathrm{~A}^{2} / \mathrm{AA}$ (Table 5 ). In $\mathrm{SR}$, this was also true for $\mathrm{BB} / \mathrm{A}^{1} \mathrm{~A}^{1} / \mathrm{EE}(P=0.04)$. In DJ, milk from cows with the composite genetic variant $\mathrm{BB} / \mathrm{BB} / \mathrm{BB}$ had higher relative concentrations of $\beta$-LG than milk from cows with $\mathrm{BC} / \mathrm{A}^{2} \mathrm{~A}^{2} / \mathrm{AB}(P=0.08)$. The variance explained by the composite genotypes on relative concentrations of $\beta$-LG was $4.3,6.1$, and $2.6 \%$ in $\mathrm{DH}$, SR, and DJ, respectively (Supplementary Table S1, http://dx.doi. org/10.3168/jds.2013-7312).

$\alpha_{S 1^{-}}$and $\alpha_{S 2^{-}} \boldsymbol{C N}$. As presented in Table 6, all composite $\alpha_{S 1}-\beta-\kappa-C N$ genotypes in SR resulted in milk with lower relative concentrations of $\alpha_{\mathrm{S}^{-}} \mathrm{CN} 9 \mathrm{P}$

Table 2. Descriptive statistics for the relative concentration of the individual milk proteins grouped by breed [Danish Holstein (DH), Swedish Red (SR), and Danish Jersey (DJ) cows], using the protein profile sample set (381 DH, 325 SR, and 221 DJ)

\begin{tabular}{|c|c|c|c|c|c|c|c|c|c|}
\hline $\begin{array}{l}\text { Protein } \\
\left(\%, \mathrm{wt} / \mathrm{wt}^{1}\right)\end{array}$ & \multicolumn{9}{|c|}{ Breed } \\
\hline$\alpha-\mathrm{LA}$ & $2.56^{\mathrm{a}}$ & 0.69 & 27.08 & $2.32^{\mathrm{b}}$ & 0.76 & 32.79 & $2.14^{\mathrm{c}}$ & 0.86 & 39.89 \\
\hline$\beta-L G$ & $10.12^{\mathrm{a}}$ & 2.17 & 21.47 & $8.80^{\mathrm{b}}$ & 1.84 & 20.89 & $8.76^{\mathrm{b}}$ & 2.71 & 30.91 \\
\hline $\mathrm{\alpha}_{\mathrm{S} 1}-\mathrm{CN} 8 \mathrm{P}$ & $21.29^{\mathrm{a}}$ & 1.70 & 7.99 & $21.65^{\mathrm{b}}$ & 1.47 & 6.78 & $23.60^{\mathrm{c}}$ & 1.88 & 7.98 \\
\hline$\alpha_{S^{2}}-\mathrm{CN}$ & $6.56^{\mathrm{a}}$ & 1.21 & 18.49 & $6.82^{\mathrm{b}}$ & 1.25 & 18.27 & $7.32^{\mathrm{c}}$ & 1.10 & 15.01 \\
\hline$\kappa-\mathrm{CN} 1 \mathrm{P}$ & $5.05^{\mathrm{a}}$ & 0.98 & 19.30 & $5.36^{\mathrm{b}}$ & 1.05 & 19.55 & $6.39^{c}$ & 0.91 & 14.21 \\
\hline $\mathrm{Adj}^{2}{ }^{2} \mathrm{k}-\mathrm{CN}$ & $10.13^{\mathrm{a}}$ & 1.31 & 12.92 & $11.69^{\mathrm{b}}$ & 1.15 & 9.86 & $11.68^{\mathrm{b}}$ & 1.09 & 9.37 \\
\hline$\beta-\mathrm{CN}$ & $38.54^{\mathrm{a}}$ & 2.70 & 7.00 & $36.99^{\mathrm{b}}$ & 2.77 & 7.49 & $36.41^{\mathrm{c}}$ & 2.94 & 8.08 \\
\hline Adj. $\beta-C N$ & $35.82^{\mathrm{a}}$ & 2.39 & 6.68 & $33.72^{\mathrm{b}}$ & 2.55 & 7.56 & $34.40^{\mathrm{c}}$ & 2.86 & 8.30 \\
\hline
\end{tabular}

${ }^{\mathrm{a}-\mathrm{c}}$ Means within a row with different superscript letters differ significantly $(P<0.05)$.

${ }^{1} \mathrm{wt} / \mathrm{wt}=\mathrm{wt} / \mathrm{wt}$ of total protein.

${ }^{2} \mathrm{Adj} .=$ adjusted average, which is adjusted for overlapping $\kappa$ - and $\beta$-CN peaks. 
Table 3. Genotype and allele frequencies of $\alpha_{\mathrm{S1}^{-}}, \beta-$, and $\kappa-\mathrm{CN}$ genotypes in Danish Holstein (DH), Swedish Red (SR), and Danish Jersey (DJ) cows in the full sample set (415 DH, $392 \mathrm{SR}$, and $406 \mathrm{DJ})$

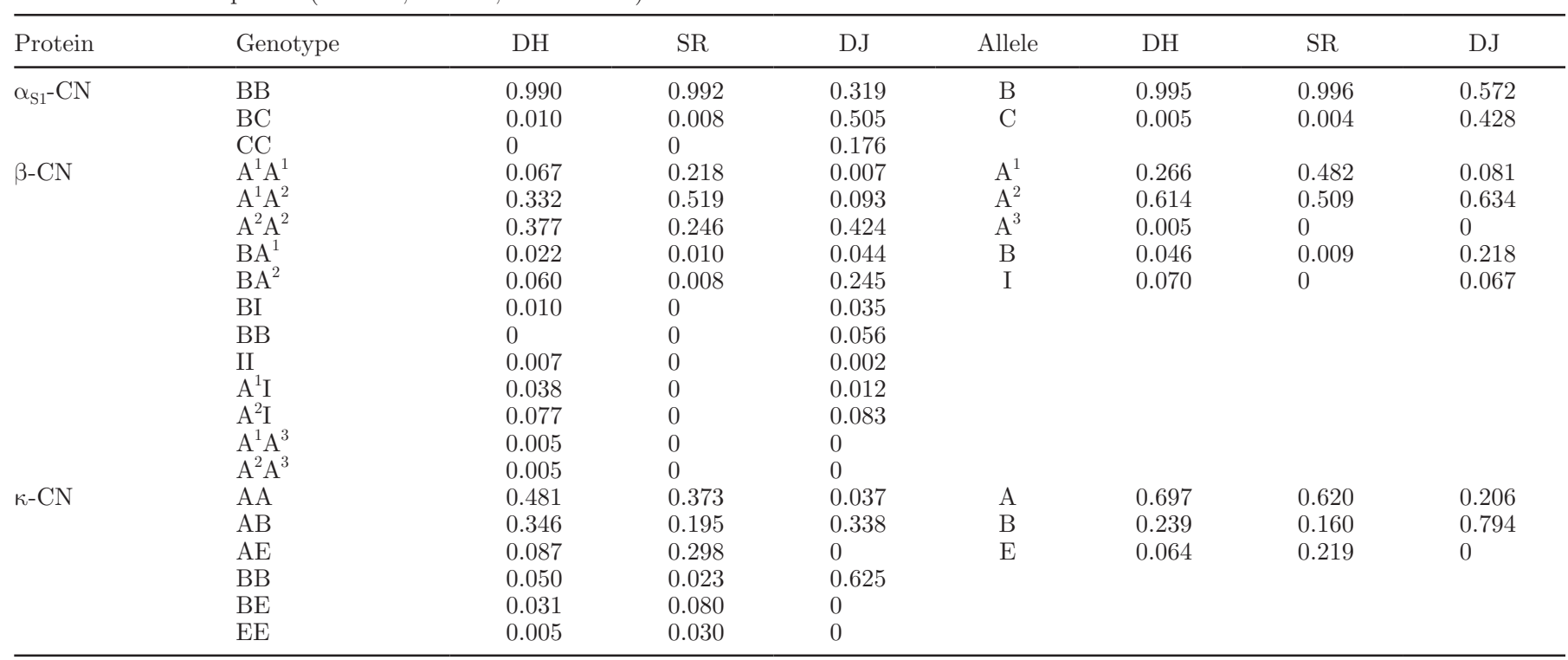

$(P=0.005-0.03)$ and total $\alpha_{\mathrm{S} 1}-\mathrm{CN}(P=0.002-0.09)$ than milk from cows with composite genotype $\mathrm{BB} /$ $\mathrm{A}^{2} \mathrm{~A}^{2} / \mathrm{AA}$. Further, all but 2 composite genotypes gave milk with lower relative concentrations of $\alpha_{\mathrm{S}^{2}} \mathrm{CN}(P$ $=0.001-0.07)$ than milk from cows with composite genotype $\mathrm{BB} / \mathrm{A}^{2} \mathrm{~A}^{2} / \mathrm{AA}$. In $\mathrm{DH}$, milk from cows with composite genotype $\mathrm{BB} / \mathrm{A}^{2} \mathrm{I} / \mathrm{AB}$ had higher relative concentrations of $\alpha_{\mathrm{S}_{2}} \mathrm{CN}(P=0.02)$ and milk from cows with the other composite genotypes had lower relative concentrations of $\alpha_{\mathrm{S}^{2}}$ - $\mathrm{CN}$ than milk from cows with $\mathrm{BB} / \mathrm{A}^{2} \mathrm{~A}^{2} / \mathrm{AA}$ (Table 6 ). Further, milk from $\mathrm{DH}$ cows with composite genotype $\mathrm{BB} / \mathrm{A}^{2} \mathrm{I} / \mathrm{AB}$ gave milk with significantly lower relative concentrations of $\alpha_{\mathrm{S}_{1}}{ }^{-}$ $\mathrm{CN} 8 \mathrm{P}, \alpha_{\mathrm{S}^{-}} \mathrm{CN} 9 \mathrm{P}$ and total $\alpha_{\mathrm{S}^{-}} \mathrm{CN}$. In DJ, cows with the composite genotype $\mathrm{BB} / \mathrm{BB} / \mathrm{BB}$ gave milk with significantly lower relative concentrations of $\alpha_{\mathrm{S1} 1} \mathrm{CN}$ $8 \mathrm{P}$ and total $\alpha_{\mathrm{S}_{1}} \mathrm{CN}$ than the most common composite genotype in $\mathrm{DJ}, \mathrm{BC} / \mathrm{A}^{2} \mathrm{~A}^{2} / \mathrm{AB}$ (Table 7 ). Further, cows with the composite genotype $\mathrm{CC} / \mathrm{A}^{2} \mathrm{~A}^{2} / \mathrm{BB}$ gave milk with higher relative concentrations of $\alpha_{\mathrm{S1}^{-}} \mathrm{CN} 9 \mathrm{P}$ and total $\alpha_{\mathrm{S}_{1}}-\mathrm{CN}$ and lower relative concentrations of $\alpha_{\mathrm{S}^{2}} \mathrm{CN}$ than cows with $\mathrm{BC} / \mathrm{A}^{2} \mathrm{~A}^{2} / \mathrm{BB}$. The variance explained by the composite genotypes on $\alpha_{\mathrm{S1}^{-}} \mathrm{CN}$ was $13.6,31.9$, and $16.9 \%$ and on $\alpha_{\mathrm{S}_{2}} \mathrm{CN}$, the variance was $16.7,35.2$, and $15.8 \%$ in DH, SR, and DJ, respectively (Supplementary Table S1, http://dx.doi.org/10.3168/ jds.2013-7312).

$\kappa-C N$. In SR, milk from cows with all composite $\alpha_{\mathrm{S}^{-}}$ $\beta-\kappa-\mathrm{CN}$ genotypes had higher relative concentrations of $\kappa$-CN 1P $(P=0.001-0.01)$ and adjusted total $\kappa-\mathrm{CN}$ $(P=0.001-0.09)$ than milk from cows with $\mathrm{BB} / \mathrm{A}^{2} \mathrm{~A}^{2} /$ AA (Table 8). In DH, milk from cows with composite genotypes $\mathrm{BB} / \mathrm{A}^{1} \mathrm{~A}^{2} / \mathrm{AA}, \mathrm{BB} / \mathrm{A}^{1} \mathrm{~A}^{2} / \mathrm{AB}$, and $\mathrm{BB} / \mathrm{BA}^{2} /$ $\mathrm{AB}$ had higher relative concentrations of $\kappa-\mathrm{CN} 1 \mathrm{P}(P$ $<0.001)$ and adjusted total $\kappa-\mathrm{CN}(P=0.01-0.06)$ than milk from cows with $\mathrm{BB} / \mathrm{A}^{2} \mathrm{~A}^{2} / \mathrm{AA}$ (Table 8 ). In

Table 4. Frequencies of the most common composite $\alpha_{\mathrm{S1}}-\beta-\kappa-\mathrm{CN}$ genotypes in Danish Holstein (DH), Danish Jersey (DJ), and Swedish Red (SR) cows using the protein profile sample set (381 DH, $325 \mathrm{SR}$, and $221 \mathrm{DJ})$

\begin{tabular}{|c|c|c|c|}
\hline \multirow{2}{*}{$\begin{array}{l}\text { Composite } \\
\text { casein genotype }\end{array}$} & \multicolumn{3}{|c|}{ Breed } \\
\hline & $\mathrm{DH}$ & SR & DJ \\
\hline $\mathrm{BB} / \mathrm{A}^{1} \mathrm{~A}^{1} / \mathrm{AA}$ & 0.019 & $0.067^{1}$ & \\
\hline $\mathrm{BB} / \mathrm{A}^{1} \mathrm{~A}^{1} / \mathrm{AE}$ & 0.011 & $0.119^{1}$ & \\
\hline $\mathrm{BB} / \mathrm{A}^{1} \mathrm{~A}^{1} / \mathrm{EE}$ & 0.005 & $0.032^{1}$ & \\
\hline $\mathrm{BB} / \mathrm{A}^{1} \mathrm{~A}^{2} / \mathrm{AA}$ & $0.146^{1}$ & $0.170^{1}$ & \\
\hline $\mathrm{BB} / \mathrm{A}^{1} \mathrm{~A}^{2} / \mathrm{AB}$ & $0.090^{1}$ & $0.077^{1}$ & $0.028^{2}$ \\
\hline $\mathrm{BB} / \mathrm{A}^{1} \mathrm{~A}^{2} / \mathrm{AE}$ & $0.080^{1}$ & $0.176^{1}$ & \\
\hline $\mathrm{BB} / \mathrm{A}^{1} \mathrm{~A}^{2} / \mathrm{BE}$ & 0.008 & $0.064^{1}$ & \\
\hline $\mathrm{BB} / \mathrm{A}^{2} \mathrm{~A}^{2} / \mathrm{AA}$ & $0.297^{1}$ & $0.131^{1}$ & $0.041^{1}$ \\
\hline $\mathrm{BB} / \mathrm{A}^{2} \mathrm{~A}^{2} / \mathrm{AB}$ & $0.080^{1}$ & $0.109^{1}$ & \\
\hline $\mathrm{BB} / \mathrm{A}^{2} \mathrm{I} / \mathrm{AB}$ & $0.069^{1}$ & & 0.018 \\
\hline $\mathrm{BB} / \mathrm{BA}^{1} / \mathrm{BB}$ & & & $0.041^{1}$ \\
\hline $\mathrm{BB} / \mathrm{BA}^{2} / \mathrm{AB}$ & $0.050^{1}$ & & $0.060^{1}$ \\
\hline $\mathrm{BB} / \mathrm{BB} / \mathrm{BB}$ & & & $0.055^{1}$ \\
\hline $\mathrm{BC} / \mathrm{A}^{1} \mathrm{~A}^{2} / \mathrm{BB}$ & & & $0.060^{1}$ \\
\hline $\mathrm{BC} / \mathrm{A}^{2} \mathrm{~A}^{2} / \mathrm{AB}$ & & 0.006 & $0.229^{1}$ \\
\hline $\mathrm{BC} / \mathrm{A}^{2} \mathrm{I} / \mathrm{BB}$ & & & $0.064^{1}$ \\
\hline $\mathrm{BC} / \mathrm{BA}^{2} / \mathrm{BB}$ & & & $0.193^{1}$ \\
\hline $\mathrm{CC} / \mathrm{A}^{2} \mathrm{~A}^{2} / \mathrm{BB}$ & & & $0.156^{1}$ \\
\hline Other $^{3}$ & 0.146 & 0.048 & 0.055 \\
\hline
\end{tabular}

${ }^{1}$ Composite casein genotypes included in the statistical model (frequency $>2.5 \%$, both in the full sample set and the protein profile sample set).

${ }^{2}$ Composite casein genotype not present at a frequency higher than $2.5 \%$ in the full sample set.

${ }^{3}$ Other refers to cows with composite genotypes with a frequency below $2.5 \%$ in all breeds. 
Table 5. Estimated differences \pm SE and trait general means \pm SD in relative concentrations of $\beta$-LG, comparing all composite $\alpha_{\mathrm{S1}}-\beta-\kappa-\mathrm{CN}$ genotypes with a frequency higher than $2.5 \%$ to the composite genotype $\mathrm{BB} / \mathrm{A}^{2} \mathrm{~A}^{2} / \mathrm{AA}$ in Danish Holstein (DH) and Swedish Red (SR) cows and to BC $/ \mathrm{A}^{2} \mathrm{~A}^{2} / \mathrm{AB}$ in Danish Jersey (DJ) cows, respectively ${ }^{1}$

\begin{tabular}{|c|c|c|c|c|}
\hline \multirow{2}{*}{$\begin{array}{l}\text { Composite } \\
\text { casein genotype }\end{array}$} & \multicolumn{2}{|c|}{$\beta-\mathrm{LG}\left(\%, \mathrm{wt} / \mathrm{wt}^{2}\right)$} & \multirow{2}{*}{$\begin{array}{l}\text { Composite } \\
\text { casein genotype }\end{array}$} & \multirow{2}{*}{$\frac{\beta-\mathrm{LG}(\%, \mathrm{wt} / \mathrm{wt})}{\text { DJ }}$} \\
\hline & $\mathrm{DH}$ & SR & & \\
\hline $\mathrm{BB} / \mathrm{A}^{2} \mathrm{~A}^{2} / \mathrm{AA}$ & 0 & 0 & $\mathrm{BC} / \mathrm{A}^{2} \mathrm{~A}^{2} / \mathrm{AB}$ & 0 \\
\hline $\mathrm{BB} / \mathrm{A}^{1} \mathrm{~A}^{1} / \mathrm{AA}$ & & $-0.13 \pm 0.50$ & $\mathrm{BB} / \mathrm{A}^{2} \mathrm{~A}^{2} / \mathrm{AA}$ & $-0.03 \pm 1.08$ \\
\hline $\mathrm{BB} / \mathrm{A}^{1} \mathrm{~A}^{1} / \mathrm{AE}$ & & $0.33 \pm 0.43$ & $\mathrm{BC} / \mathrm{BA}^{2} / \mathrm{BB}$ & $-0.16 \pm 0.61$ \\
\hline $\mathrm{BB} / \mathrm{A}^{1} \mathrm{~A}^{1} / \mathrm{EE}$ & & $1.40 \pm 0.64^{*}$ & $\mathrm{CC} / \mathrm{A}^{2} \mathrm{~A}^{2} / \mathrm{BB}$ & $0.34 \pm 0.63$ \\
\hline $\mathrm{BB} / \mathrm{A}^{1} \mathrm{~A}^{2} / \mathrm{AA}$ & $0.34 \pm 0.37$ & $0.20 \pm 0.38$ & BB/BB/BB & $1.65 \pm 0.92 \dagger$ \\
\hline $\mathrm{BB} / \mathrm{A}^{1} \mathrm{~A}^{2} / \mathrm{AB}$ & $1.10 \pm 0.45^{*}$ & $0.83 \pm 0.48 \dagger$ & $\mathrm{BB} / \mathrm{BA}^{2} / \mathrm{AB}$ & $0.66 \pm 0.91$ \\
\hline $\mathrm{BB} / \mathrm{A}^{1} \mathrm{~A}^{2} / \mathrm{AE}$ & $0.65 \pm 0.46$ & $0.28 \pm 0.38$ & $\mathrm{BC} / \mathrm{A}^{2} \mathrm{I} / \mathrm{BB}$ & $-0.10 \pm 0.87$ \\
\hline $\mathrm{BB} / \mathrm{A}^{1} \mathrm{~A}^{2} / \mathrm{BE}$ & & $0.80 \pm 0.52$ & $\mathrm{BC} / \mathrm{A}^{1} \mathrm{~A}^{2} / \mathrm{BB}$ & $-0.18 \pm 0.89$ \\
\hline $\mathrm{BB} / \mathrm{A}^{2} \mathrm{~A}^{2} / \mathrm{AB}$ & $0.34 \pm 0.48$ & $0.17 \pm 0.42$ & $\mathrm{BB} / \mathrm{BA}^{1} / \mathrm{BB}$ & $-0.40 \pm 1.09$ \\
\hline $\mathrm{BB} / \mathrm{A}^{2} \mathrm{I} / \mathrm{AB}$ & $-0.11 \pm 0.50$ & & & \\
\hline $\mathrm{BB} / \mathrm{BA}^{2} / \mathrm{AB}$ & $0.51 \pm 0.56$ & & & \\
\hline Trait mean & $10.12 \pm 2.17$ & $8.80 \pm 1.84$ & Trait mean & $8.76 \pm 2.71$ \\
\hline
\end{tabular}

${ }^{1}$ Cows from the protein profile subset were used (309 DH, 309 SR, and 199 DJ).

${ }^{2} \mathrm{wt} / \mathrm{wt}=\mathrm{wt} / \mathrm{wt}$ of total protein.

$\dagger P<0.1 ; * P<0.05$.

DJ, milk from cows with the composite genotype $\mathrm{BC} /$ $\mathrm{A}^{1} \mathrm{~A}^{2} / \mathrm{BB}$ had significantly higher relative concentration of $\kappa-\mathrm{CN} 1 \mathrm{P}(P=0.001)$ and higher adjusted total k-CN $(P=0.08)$ than milk from cows with $\mathrm{BC} / \mathrm{A}^{2} \mathrm{~A}^{2} /$ $\mathrm{BB}$ (Table 7). The variance explained by the composite genotypes on $\kappa-\mathrm{CN} 1 \mathrm{P}$ was $32.9,87.0$, and $10.2 \%$, and on adjusted total $\kappa$-CN, the variance was $7.9,55.8$, and $5.8 \%$ in DH, SR, and DJ, respectively (Supplementary Table S1, http://dx.doi.org/10.3168/jds.2013-7312).

$\boldsymbol{\beta}-\boldsymbol{C N}$. In $\mathrm{DH}$, milk from cows with composite $\alpha_{\mathrm{S}^{-}}$ $\beta$ - $\kappa$-CN genotypes $\mathrm{BB} / \mathrm{A}^{1} \mathrm{~A}^{2} / \mathrm{AA}, \mathrm{BB} / \mathrm{A}^{1} \mathrm{~A}^{2} / \mathrm{AE}$, and $\mathrm{BB} / \mathrm{BA}^{2} / \mathrm{AB}$ had higher relative concentrations of total $\beta-\mathrm{CN}$ and adjusted total $\beta-\mathrm{CN}(P=0.001-0.08)$ than milk from cows with $\mathrm{BB} / \mathrm{A}^{2} \mathrm{~A}^{2} / \mathrm{AA}$ (Table 8 ). Further, milk from cows with $\mathrm{BB} / \mathrm{A}^{1} \mathrm{~A}^{2} / \mathrm{AB}$ had significantly higher relative concentrations of total $\beta-\mathrm{CN}(P<0.001)$ than milk from cows with $\mathrm{BB} / \mathrm{A}^{2} \mathrm{~A}^{2} / \mathrm{AA}$. In $\mathrm{SR}$, milk from cows with all but $\mathrm{BB} / \mathrm{A}^{1} \mathrm{~A}^{1} / \mathrm{EE}, \mathrm{BB} / \mathrm{A}^{2} \mathrm{~A}^{2} / \mathrm{AB}$, and $\mathrm{BB} / \mathrm{A}^{1} \mathrm{~A}^{1} / \mathrm{AE}$ had significantly higher relative concentrations of $\beta-\mathrm{CN}(P=0.001-0.05)$ than milk from cows with $\mathrm{BB} / \mathrm{A}^{2} \mathrm{~A}^{2} / \mathrm{AA}$ (Table 8 ). Regarding the relative concentration of adjusted total $\beta-\mathrm{CN}$, milk from cows with $\mathrm{BB} / \mathrm{A}^{1} \mathrm{~A}^{2} / \mathrm{AB}, \mathrm{BB} / \mathrm{A}^{1} \mathrm{~A}^{2} / \mathrm{BE}, \mathrm{BB} / \mathrm{A}^{1} \mathrm{~A}^{1} / \mathrm{AA}$, and $\mathrm{BB} / \mathrm{A}^{1} \mathrm{~A}^{1} / \mathrm{AE}$ had significantly higher relative concentrations $(P=0.02-0.09)$ than milk from cows with $\mathrm{BB} / \mathrm{A}^{2} \mathrm{~A}^{2} / \mathrm{AA}$. In $\mathrm{DJ}$, milk from cows with $\mathrm{BC} / \mathrm{BA}^{2} /$ $\mathrm{BB}, \mathrm{BC} / \mathrm{A}^{1} \mathrm{~A}^{2} / \mathrm{BB}$, and $\mathrm{BB} / \mathrm{BA}^{1} / \mathrm{BB}$ had higher relative concentrations of $\beta-\mathrm{CN}$ and adjusted total $\beta-\mathrm{CN}$ $(P=0.001-0.09)$ than milk from cows with $\mathrm{BC} / \mathrm{A}^{2} \mathrm{~A}^{2} /$ $\mathrm{BB}$ (Table 7 ). The variance explained by the composite genotypes on $\beta$-CN was $53.8,66.3$, and $20.8 \%$, and on adjusted total $\beta-\mathrm{CN}$, the variance was $7.8,12.3$, and $15.3 \%$ in DH, SR, and DJ, respectively (Supplementary Table S1, http://dx.doi.org/10.3168/jds.2013-7312).

\section{DISCUSSION}

\section{Effect of Breed on Protein Profile}

The results from this study show a significant effect of breed on relative concentrations of all individual proteins. Studies reporting breed differences in protein profile are scarce; however, a few studies have reported breed effects on absolute concentrations of the individual milk proteins (e.g., McLean et al., 1984; Auldist et al., 2004; Wedholm et al., 2006). It could be misleading to compare the present work with those studies, as relative concentrations might not increase or decrease in the same direction as absolute concentrations (Hallén et al., 2008). However, those studies confirm that breed differences are to be expected. As DH samples were collected in the autumn, the DJ samples in the winter, and the SR samples in both winter and autumn, season could be a confounding factor when estimating breed effects. However, Heck et al. (2009b) and LindmarkMånsson et al. (2003) argued that most of the seasonal variation depends on the diet change during the grazing season and the samples collected in the current study was collected before and after the grazing season.

Interestingly, the present study showed that DH milk had the lowest relative concentrations of $\kappa-\mathrm{CN} 1 \mathrm{P}$ and the highest relative concentrations of $\beta-\mathrm{CN}$ of the 3 breeds. This was also true when correcting for hidden $\kappa-\mathrm{CN}$ peaks, adjusted total $\kappa-\mathrm{CN}$, and adjusted total $\beta-\mathrm{CN}$. However, looking at the differences between DJ and SR, DJ milk had higher relative concentrations of $\kappa-\mathrm{CN} 1 \mathrm{P}$ than SR milk but the relative concentrations of adjusted total $\kappa$-CN did not differ. This suggests that SR milk contains higher relative concentrations of glycosylated $\kappa-\mathrm{CN}$ than DJ milk. This is important, as variations in 
Table 6. Estimated differences $\pm \mathrm{SE}$ and trait general means $\pm \mathrm{SD}$ in relative concentrations of $\alpha_{\mathrm{S2}^{-}}$and $\alpha_{\mathrm{S1} 1^{-}} \mathrm{CN}$, comparing all composite $\alpha_{\mathrm{S1} 1^{-}} \beta-\kappa-\mathrm{CN}$ genotypes with a frequency higher than $2.5 \%$ to the composite genotype BB $/ \mathrm{A}^{2} \mathrm{~A}^{2} / \mathrm{AA}$ in Danish Holstein (DH) and Swedish Red (SR) cows, respectively ${ }^{1}$

\begin{tabular}{|c|c|c|c|c|c|c|c|c|}
\hline \multirow{2}{*}{$\begin{array}{l}\text { Composite } \\
\text { casein genotype }\end{array}$} & \multicolumn{2}{|c|}{$\alpha_{\mathrm{S}^{-}} \mathrm{CN} 8 \mathrm{P}\left(\%, \mathrm{wt} / \mathrm{wt}^{2}\right)$} & \multicolumn{2}{|c|}{$\alpha_{\mathrm{S} 1}-\mathrm{CN} 9 \mathrm{P}(\%, \mathrm{wt} / \mathrm{wt})$} & \multicolumn{2}{|c|}{$\alpha_{\mathrm{S}^{-}} \mathrm{CN}(\%, \mathrm{wt} / \mathrm{wt})$} & \multicolumn{2}{|c|}{$\alpha_{\mathrm{S}_{2}} \mathrm{CN}(\%, \mathrm{wt} / \mathrm{wt})$} \\
\hline & DH & SR & $\mathrm{DH}$ & SR & DH & SR & DH & SR \\
\hline $\mathrm{BB} / \mathrm{A}^{2} \mathrm{~A}^{2} / \mathrm{AA}$ & 0 & 0 & 0 & 0 & 0 & 0 & 0 & 0 \\
\hline $\mathrm{BB} / \mathrm{A}^{1} \mathrm{~A}^{1} / \mathrm{AA}$ & & $-0.38 \pm 0.40$ & & $-0.71 \pm 0.27^{*}$ & & $-1.03 \pm 0.43^{*}$ & & $-0.68 \pm 0.34 \dagger$ \\
\hline $\mathrm{BB} / \mathrm{A}^{1} \mathrm{~A}^{1^{1}} / \mathrm{AE}$ & & $-0.02 \pm 0.34$ & & $-0.58 \pm 0.24^{*}$ & & $-0.65 \pm 0.37 \dagger$ & & $-1.11 \pm 0.29^{* * *}$ \\
\hline $\mathrm{BB} / \mathrm{A}^{1} \mathrm{~A}^{1} / \mathrm{EE}$ & & $-0.04 \pm 0.52$ & & $-0.79 \pm 30.35^{*}$ & & $-1.00 \pm 0.56 \dagger$ & & $-0.90 \pm 0.43^{*}$ \\
\hline $\mathrm{BB} / \mathrm{A}^{1} \mathrm{~A}^{2^{2}} / \mathrm{AA}$ & $-0.28 \pm 0.28$ & $-0.40 \pm 0.31$ & $-0.14 \pm 0.23$ & $-0.59 \pm 0.21^{* *}$ & $-0.48 \pm 0.33$ & $-1.10 \pm 0.33^{* *}$ & $-0.34 \pm 0.19 \dagger$ & $-0.17 \pm 0.26$ \\
\hline $\mathrm{BB} / \mathrm{A}^{1} \mathrm{~A}^{2^{\prime}} / \mathrm{AB}$ & $-0.69 \pm 0.34^{*}$ & $-0.66 \pm 0.39 \dagger$ & $-0.43 \pm 0.27$ & $-0.62 \pm 0.26^{*}$ & $-1.21 \pm 0.40^{* *}$ & $-1.38 \pm 0.42^{* *}$ & $-0.62 \pm 0.23^{*}$ & $-1.17 \pm 0.32^{* *}$ \\
\hline $\mathrm{BB} / \mathrm{A}^{1} \mathrm{~A}^{2} / \mathrm{AE}$ & $-0.40 \pm 0.34$ & $0.08 \pm 0.31$ & $0.13 \pm 0.28$ & $-0.63 \pm 0.21^{* *}$ & $-0.48 \pm 0.41$ & $-0.57 \pm 0.33 \dagger$ & $-0.49 \pm 0.23^{*}$ & $-0.08 \pm 0.26$ \\
\hline $\mathrm{BB} / \mathrm{A}^{1} \mathrm{~A}^{2} / \mathrm{BE}$ & & $-0.47 \pm 0.41$ & & $-0.71 \pm 0.29^{*}$ & & $-1.17 \pm 0.44^{*}$ & & $-1.63 \pm 0.35^{* * *}$ \\
\hline $\mathrm{BB} / \mathrm{A}^{2} \mathrm{~A}^{2} / \mathrm{AB}$ & $-0.11 \pm 0.36$ & $-0.63 \pm 0.34 \dagger$ & $-0.33 \pm 0.29$ & $-0.51 \pm 0.23^{*}$ & $-0.40 \pm 0.42$ & $-1.12 \pm 0.37^{* *}$ & $-0.69 \pm 0.24^{* *}$ & $-0.52 \pm 0.28 \dagger$ \\
\hline $\mathrm{BB} / \mathrm{A}^{2} \mathrm{I} / \mathrm{AB}$ & $-0.80 \pm 0.37^{*}$ & & $-1.07 \pm 0.30^{* *}$ & & $-1.82 \pm 0.44^{* * *}$ & & $0.64 \pm 0.25^{*}$ & \\
\hline $\mathrm{BB} / \mathrm{BA}^{2} / \mathrm{AB}$ & $-0.49 \pm 0.41$ & & $-0.25 \pm 0.34$ & & $-0.86 \pm 0.50 \dagger$ & & $-0.91 \pm 0.28^{* *}$ & \\
\hline Trait mean & $21.29 \pm 1.70$ & $21.65 \pm 1.47$ & $6.53 \pm 1.39$ & $6.43 \pm 1.10$ & $29.06 \pm 2.03$ & $29.33 \pm 1.56$ & $6.56 \pm 1.21$ & $6.82 \pm 1.25$ \\
\hline
\end{tabular}

${ }^{1}$ Cows from the protein profile subset were used (309 DH and $309 \mathrm{SR}$ )

${ }^{2} \mathrm{wt} / \mathrm{wt}=\mathrm{wt} / \mathrm{wt}$ of total protein.

$\dagger P<0.1 ; * P<0.05 ; * * P<0.01 ; * * * P<0.001$.

Table 7. Estimated differences $\pm \mathrm{SE}$ and trait general means \pm SD in relative concentrations of $\alpha_{\mathrm{S}^{-}}, \alpha_{\mathrm{S}^{-}}, \kappa-$, and $\beta$-CN, comparing all composite $\alpha_{\mathrm{S}^{-}}-\beta-\kappa-\mathrm{CN}$ genotypes with a frequency higher than $2.5 \%$ to the composite genotype $\mathrm{BC} / \mathrm{A}^{2} \mathrm{~A}^{2} / \mathrm{AB}$ in Danish Jersey (DJ) cows

\begin{tabular}{|c|c|c|c|c|c|c|c|c|}
\hline \multirow{2}{*}{$\begin{array}{l}\text { Composite } \\
\text { casein genotype }\end{array}$} & \multicolumn{8}{|c|}{ Concentration $\left(\%, \mathrm{wt} / \mathrm{wt}^{2}\right)$} \\
\hline & $\alpha_{\mathrm{S}^{-}} \mathrm{CN} 8 \mathrm{P}$ & $\alpha_{\mathrm{S} 1}-\mathrm{CN} 9 \mathrm{P}$ & $\alpha_{\mathrm{S} 1}-\mathrm{CN}$ & $\alpha_{\mathrm{S}^{2}} \mathrm{CN}$ & $\kappa-\mathrm{CN} 1 \mathrm{P}$ & Adj. ${ }^{3} \kappa-C N$ & $\beta-\mathrm{CN}$ & Adj. $\beta-\mathrm{CN}$ \\
\hline$\overline{\mathrm{BC} / \mathrm{A}^{2} \mathrm{~A}^{2} / \mathrm{AB}}$ & 0 & 0 & 0 & 0 & 0 & 0 & $\overline{0}$ & 0 \\
\hline $\mathrm{BB} / \mathrm{A}^{2} \mathrm{~A}^{2} / \mathrm{AA}$ & $0.64 \pm 0.67$ & $0.24 \pm 0.42$ & $0.53 \pm 0.89$ & $-0.63 \pm 0.39$ & $-0.12 \pm 0.34$ & $-0.43 \pm 0.41$ & $1.66 \pm 1.04$ & $1.72 \pm 1.03 \dagger$ \\
\hline $\mathrm{BC} / \mathrm{BA}^{2} / \mathrm{BB}$ & $-0.27 \pm 0.38$ & $0.26 \pm 0.23$ & $-0.15 \pm 0.50$ & $-0.52 \pm 0.22^{*}$ & $0.35 \pm 0.19 \dagger$ & $0.12 \pm 0.24$ & $1.65 \pm 0.59^{* *}$ & $0.98 \pm 0.58 \dagger$ \\
\hline $\mathrm{CC} / \mathrm{A}^{2} \mathrm{~A}^{2} / \mathrm{BB}$ & $0.62 \pm 0.39$ & $0.78 \pm 0.24^{* * *}$ & $1.28 \pm 0.52^{*}$ & $-0.68 \pm 0.23^{* *}$ & $-0.10 \pm 0.20$ & $-0.47 \pm 0.24 \dagger$ & $-0.62 \pm 0.60$ & $-0.56 \pm 0.60$ \\
\hline BB/BB/BB & $-2.27 \pm 0.57^{* * *}$ & $-0.26 \pm 0.35$ & $-2.95 \pm 0.76^{* * *}$ & $-0.23 \pm 0.34$ & $0.21 \pm 0.30$ & $-0.01 \pm 0.36$ & $0.03 \pm 0.89$ & $1.17 \pm 0.88$ \\
\hline $\mathrm{BB} / \mathrm{BA}^{2} / \mathrm{AB}$ & $-0.72 \pm 0.56$ & $0.26 \pm 0.35$ & $-0.77 \pm 0.75$ & $-0.45 \pm 0.33$ & $-0.03 \pm 0.29$ & $-0.28 \pm 0.35$ & $1.35 \pm 0.88$ & $0.72 \pm 0.87$ \\
\hline $\mathrm{BC} / \mathrm{A}^{2} \mathrm{I} / \mathrm{BB}$ & $-0.89 \pm 0.54$ & $-0.05 \pm 0.34$ & $-0.90 \pm 0.72$ & $0.44 \pm 0.32$ & $0.14 \pm 0.27$ & $0.08 \pm 0.33$ & $0.04 \pm 0.84$ & $0.11 \pm 0.83$ \\
\hline $\mathrm{BC} / \mathrm{A}^{1} \mathrm{~A}^{2} / \mathrm{BB}$ & $-0.17 \pm 0.55$ & $0.02 \pm 0.34$ & $-0.39 \pm 0.73$ & $-0.10 \pm 0.32$ & $0.96 \pm 0.27^{* * *}$ & $0.57 \pm 0.33 \dagger$ & $2.96 \pm 0.84^{* * *}$ & $2.26 \pm 0.83^{*}$ \\
\hline $\mathrm{BB} / \mathrm{BA}^{1} / \mathrm{BB}$ & $-0.82 \pm 0.67$ & $-0.03 \pm 0.42$ & $-1.35 \pm 0.90$ & $-0.48 \pm 0.40$ & $-0.03 \pm 0.35$ & $0.37 \pm 0.42$ & $2.42 \pm 1.05^{*}$ & $2.81 \pm 1.04^{*}$ \\
\hline Trait mean & $23.60 \pm 1.88$ & $6.21 \pm 1.14$ & $31.51 \pm 2.55$ & $7.32 \pm 1.10$ & $6.39 \pm 0.91$ & $11.68 \pm 1.09$ & $36.41 \pm 2.94$ & $34.40 \pm 2.86$ \\
\hline
\end{tabular}

$\lesssim \quad{ }^{1}$ Cows from the protein profile subset were used (199 DJ).

$\stackrel{0}{\varphi}{ }^{2} \mathrm{wt} / \mathrm{wt}=\mathrm{wt} / \mathrm{wt}$ of total protein.

$\underset{\mathbf{z}}{3} \mathrm{Adj}$. = adjusted average, which is adjusted for overlapping $\kappa$ - and $\beta$-CN peaks 
glycosylation of $\kappa$ - $\mathrm{CN}$ affects $\mathrm{CN}$ micelle stability and, in turn, milk processability (Holland, 2008).

\section{Genotype Frequencies}

The allele and genotype frequencies in the present study have earlier been published and discussed by Poulsen et al. (2013). Regarding frequencies of composite $\alpha_{\mathrm{S} 1}-\beta-\kappa-\mathrm{CN}$ genotypes, differences can be observed in all 3 breeds compared with earlier studies (Bech and Kristiansen, 1990; Lundén et al., 1997). It is evident that in the last 10 to $20 \mathrm{yr}$, a decrease in cows with $\mathrm{BB} / \mathrm{A}^{1} \mathrm{~A}^{1} / \mathrm{AA}$ (from $\sim 20$ to $\sim 2 \%$ in our study) and $\mathrm{BB} / \mathrm{A}^{1} \mathrm{~A}^{2} / \mathrm{AA}$ (from $\sim 40$ to $\sim 15 \%$ in our study) has occurred in both DH (Bech and Kristiansen, 1990) and SR (Lundén et al., 1997). Furthermore, a drastic increase of cows with $\mathrm{BB} / \mathrm{A}^{2} \mathrm{~A}^{2} / \mathrm{AA}$ has occurred in in $\mathrm{DH}$ (from 9 to $30 \%$ in our study; Bech and Kristiansen, 1990) and $\mathrm{BB} / \mathrm{A}^{1} \mathrm{~A}^{2} / \mathrm{AE}$ in $\mathrm{SR}$ (from $0 \%$ to $18 \%$ in our study; Lundén et al., 1997). In DJ, the number of cows with the composite $\alpha_{\mathrm{S} 1}-\beta-\kappa-\mathrm{CN}$ genotype $\mathrm{BB} / \mathrm{BA}^{2} / \mathrm{AB}$ has decreased (from 20 to $6 \%$ in our study) and the number of cows with $\mathrm{CC} / \mathrm{A}^{2} \mathrm{~A}^{2} / \mathrm{BB}$ have increased (from $<7$ to $16 \%$ in our study) compared with the number observed by Bech and Kristiansen (1990). The results presented here confirm earlier studies, that casein variants affect both milk composition and milk yields (Bovenhuis et al., 1992; Ikonen et al., 1999; Heck et al., 2009a). Current breeding goals may have induced a change in the genotype frequencies of the studied breeds. In turn, this may have large effects on the protein profile and technological properties of different dairy products.

\section{Effect of Composite Genotypes}

The concentration and conformation of $\beta$-LG affects properties of many different milk products and is especially important in the production of fermented products and milk powders (Anema, 2008; Lucey, 2008). In the present study, only a few composite $\alpha_{\mathrm{S} 1}-\beta-\kappa-\mathrm{CN}$ genotypes affected relative concentrations of $\beta-\mathrm{LG}$, which indicates that these composite genotypes would not be suitable markers for altering $\beta$-LG content in DH, SR, and DJ breeds. Visker et al. (2011) previously showed that Holstein-Friesian cows homozygous for $\beta$ - $-\mathrm{CN}$ haplotype $\mathrm{A}^{2} / \mathrm{A}$ gave milk with higher relative concentrations of $\beta-\mathrm{LG}$ compared with cows with alternate genotypes. However, in the present study, the composite genotypes that affected relative concentrations of $\beta$-LG were associated with higher relative concentrations of $\beta$-LG than $\mathrm{BB} / \mathrm{A}^{2} \mathrm{~A}^{2} / \mathrm{AA}$. It is known that genetic variants of $\beta-\mathrm{LG}$ can affect relative concentrations of $\beta$-LG (Heck et al., 2009a) and as these genetic variants are not accounted for in the models 
used in the present study or in the study by Visker et al. (2011), this could explain the inconsistencies. To be able to breed cows with altered whey protein content, it is probable that genetic variants of $\beta$-LG must be considered.

Caseins are important for many different dairy products and especially in cheese where they are the building blocks in the cheese gel network (Walstra et al., 2006). Most of the composite genotypes in SR and many of the composite genotypes in $\mathrm{DH}$ were associated with low relative concentrations of $\alpha_{\mathrm{S1}^{-}}$and $\alpha_{\mathrm{S}_{2}} \mathrm{CN}$ and high relative concentrations of $\kappa$ - and $\beta-\mathrm{CN}$ compared with the common composite genotype $\mathrm{BB} / \mathrm{A}^{2} \mathrm{~A}^{2} / \mathrm{AA}$. In addition to $\mathrm{BB} / \mathrm{A}^{2} \mathrm{~A}^{2} / \mathrm{AA}, 4$ of the other composite genotypes had frequencies above $2.5 \%$ in both $\mathrm{DH}$ and SR and it might be expected that the effects of these composite genotypes on protein profile would be the same in both breeds. Both SR and DH cows with the composite genotype $\mathrm{BB} / \mathrm{A}^{1} \mathrm{~A}^{2} / \mathrm{AB}$ gave milk with lower relative concentrations of $\alpha_{\mathrm{S1}^{-}}$and $\alpha_{\mathrm{S}^{-}} \mathrm{CN}$ as well as higher relative concentrations of $\kappa-\mathrm{CN} 1 \mathrm{P}$, adjusted total $\kappa-\mathrm{CN}$ and $\beta-\mathrm{CN}$ than $\mathrm{SR}$ and $\mathrm{DH}$ cows with $\mathrm{BB} /$ $\mathrm{A}^{2} \mathrm{~A}^{2} / \mathrm{AA}$. However, regarding the other composite genotypes, the effects were not as consequent across SR and DH. An explanation for this could be that many more composite genetic variants were present at low frequencies in $\mathrm{DH}$ than in SR. This means that $20 \%$ of the DH cows were not accounted for in this comparison, whereas only $5 \%$ were not accounted for in SR.

To our knowledge, the only study investigating the effect of composite $\alpha_{S_{1}}-\beta-\kappa-C N$ genotypes on relative concentrations of milk proteins is that of Ehrmann et al. (1997). However, Ehrmann et al. (1997) did not account for relationships between animals, in contrast to the present study, and their results could be biased, as 8 different breeds were investigated simultaneously even though all composite genotypes were not present in all breeds. Therefore, it is not appropriate to compare the results from the present study with Ehrmann et al. (1997). However, studies exist investigating the effect of composite $\beta$ - $\kappa$-CN haplotypes on relative concentrations of the milk proteins. Visker et al. (2011) found that the relative concentration of $\alpha_{\mathrm{S}_{1}}$ CN was significantly higher and that the relative concentrations of $\kappa-\mathrm{CN} 1 \mathrm{P}$ and $\beta-\mathrm{CN}$ were lower in milk from Dutch Holstein-Friesian cows homozygous for $\beta-\kappa-\mathrm{CN}$ haplotype $\mathrm{A}^{2} / \mathrm{A}$ than in milk from cows not carrying this haplotype. Further, Bonfatti et al. (2010b) found that the $\beta-\kappa-C N$ haplotype $\mathrm{A}^{2} / \mathrm{A}$ was associated with lower relative concentrations (per total casein) of $\alpha_{\mathrm{S1}^{-}}$and $\alpha_{\mathrm{S}_{2}} \mathrm{CN}$ and higher relative concentrations of $\kappa-\mathrm{CN}$ in Italian Simmental cows. The effect of $\beta-\kappa-\mathrm{CN}$ haplotype $\mathrm{A}^{2} / \mathrm{A}$ on $\beta-\mathrm{CN}$ was not as obvious. The effects of composite $\alpha_{\mathrm{S} 1}-\beta-\kappa-\mathrm{CN} \mathrm{BB} / \mathrm{A}^{2} \mathrm{~A}^{2} / \mathrm{AA}$ on relative concentrations of the caseins in the present study are, therefore, corroborated both by what has been seen in Dutch Holstein-Friesian (Visker et al., 2011) and in Italian Simmental (Bonfatti et al., 2010b) cows.

The recently discovered $\beta$-CN I variant in European cattle breeds (Jann et al., 2002) is present both in DH and DJ. Interestingly, $\mathrm{DH}$ cows with the composite genotype $\mathrm{BB} / \mathrm{A}^{2} \mathrm{I} / \mathrm{AB}$ and $\mathrm{DJ}$ cows with $\mathrm{BC} / \mathrm{A}^{2} \mathrm{I} / \mathrm{BB}$ gave milk with higher relative concentrations of $\alpha_{\mathrm{S}_{2}-} \mathrm{CN}$ than cows with $\mathrm{BB} / \mathrm{A}^{2} \mathrm{~A}^{2} / \mathrm{AA}$. This agrees with Visker et al. (2011), who found that $\beta$ - $\kappa-C N$ haplotype I/B was the only haplotype associated with higher relative concentrations of $\alpha_{S_{2}}-\mathrm{CN}$. Visker et al. (2011) also found that casein haplotype I/B was associated with lower relative concentrations of $\alpha_{S_{1}}-\mathrm{CN}$ and higher relative concentrations of $\kappa-\mathrm{CN} 1 \mathrm{P}$, which agrees with the present study regarding relative concentrations of $\alpha_{\mathrm{S} 1}-\mathrm{CN}$. Both Jensen et al. (2012) and Jõudu et al. (2008) suggest that higher relative concentrations of $\alpha_{\mathrm{S} 2}-\mathrm{CN}$ are associated with poor coagulation in rennet gels, which indicates that an increase in the $\beta$-CN I variant in $\mathrm{DH}$ and DJ could have a negative effect on milk coagulation properties of the milk from these breeds.

In DJ, the effects of composite $\alpha_{S 1}-\beta-\kappa-C N$ genotypes on relative concentrations of the milk proteins are not as evident as in the other 2 breeds. Notably, $\mathrm{CC} / \mathrm{A}^{2} \mathrm{~A}^{2} /$ $\mathrm{BB}$ is the only composite genotype in the 3 breeds that is associated with high levels of $\alpha_{\mathrm{S1}}$-CN compared with the most common composite genotype. Furthermore, composite genotype $\mathrm{BC} / \mathrm{A}^{1} \mathrm{~A}^{2} / \mathrm{BB}$ was found to be favorable for high relative concentrations of $\kappa-\mathrm{CN} 1 \mathrm{P}$ and adjusted total $\kappa-\mathrm{CN}$ as well as high relative concentrations of $\beta$-CN compared with the most common DJ composite genotype $\mathrm{BC} / \mathrm{A}^{2} \mathrm{~A}^{2} / \mathrm{AB}$. As $\mathrm{CC} / \mathrm{A}^{2} \mathrm{~A}^{2} / \mathrm{BB}$ is the third most common composite genotype in $\mathrm{DJ}$ (15.6\%; Table 4) this composite genotype could be one of the reasons for the higher relative concentration of $\alpha_{\mathrm{S} 1}-\mathrm{CN}$ in DJ compared with SR and DH. Furthermore, $\mathrm{BC} / \mathrm{A}^{1} \mathrm{~A}^{2} / \mathrm{BB}$ is present in only $6 \%$ of $\mathrm{DJ}$ and, therefore, it can be used as a marker for increased relative concentrations of $\kappa$ - and $\beta-\mathrm{CN}$ in DJ, which could be favorable for, as an example, rennet-induced and acidinduced gelation (Lucey, 2008).

\section{Possible Effects on Milk Processability}

Lindmark-Månsson et al. (2003) found a significant decrease in casein content and a subsequent increase in whey proteins in Swedish dairy milk from 1970 to 1996, whereas no change in total protein concentration was observed. The authors suggested that this indicated a change in the distribution of different milk proteins and that this change could partly be due to selection strategies in dairy cows. As the present study has shown 
a significant effect of composite genotypes on detailed protein composition, changes in frequencies could affect the functionality of dairy milk. Compared with earlier studies (Bech and Kristiansen, 1990; Lundén et al., 1997), the frequencies of the different composite genotypes have changed drastically. When looking at the results from the present study, it is possible that the increase in $\mathrm{DH}$ and $\mathrm{SR}$ cows with composite genotype $\mathrm{BB} / \mathrm{A}^{2} \mathrm{~A}^{2} / \mathrm{AA}$ has resulted in milk with higher relative concentrations of $\alpha_{S^{-}}$and $\alpha_{S 2^{-}} \mathrm{CN}$ and lower relative concentrations of $\kappa-$ and $\beta-\mathrm{CN}$. This indicates that if the relationships between genetics and milk composition are not known and not properly accounted for in breeding programs, then a risk exists for milk composition to become less suitable for processing of various dairy products.

The lower relative concentrations of $\kappa$ - and $\beta-\mathrm{CN}$ and higher relative concentrations of $\alpha_{S^{-}} \mathrm{CN}$, which is associated with $\alpha_{S 1}-\beta-\kappa-C N$ genotype $B B / A^{2} A^{2} / A A$, could be the underlying reason for the poor rennet-induced gelation properties observed for $\mathrm{BB} / \mathrm{A}^{2} \mathrm{~A}^{2} / \mathrm{AA}$ cows in Poulsen et al. (2013). Likewise, this and other studies have shown that milk from Jersey cows have superior coagulation properties compared with Holstein-Friesian cows (Auldist et al., 2004; Frederiksen et al., 2011b; Poulsen et al., 2013). Jensen et al. (2012) found that within the DJ and DH breeds, significantly higher protein and casein contents existed as well as higher relative concentrations of $\kappa-\mathrm{CN}$ (in both $\mathrm{DH}$ and $\mathrm{DJ}$ ) and lower relative concentrations of $\alpha_{\mathrm{S}_{2}} \mathrm{CN}$ (only in DJ) in well-coagulating milk than poorly coagulating milk. The relative concentrations of $\beta-\mathrm{CN}$ and $\alpha_{\mathrm{S} 1}-\mathrm{CN}$ did not differ between these groups. Frederiksen et al. (2011a) and Jensen et al. (2012) found that a higher proportion of the more phosphorylated forms of $\alpha_{\mathrm{S1}^{-}}$ and $\alpha_{\mathrm{S}^{2}} \mathrm{CN}$ were associated with non- and poorly coagulating milk in DH. As the DJ breed gives milk with a higher relative concentration of $\alpha_{\mathrm{S}_{1}} \mathrm{CN} 8 \mathrm{P}$ than $\mathrm{DH}$ together with the differences in protein profiles as well as in protein and casein contents, this could explain the superior coagulation properties in DJ.

The present work suggest that a higher frequency of $\mathrm{BB} / \mathrm{A}^{1} \mathrm{~A}^{2} / \mathrm{AB}$, which is present in $8 \%$ of $\mathrm{SR}$ and $9 \%$ of $\mathrm{DH}$, together with a decrease in $\mathrm{BB} / \mathrm{A}^{2} \mathrm{~A}^{2} / \mathrm{AA}$ could have positive effects on $\mathrm{DH}$ and SR milk, as the relative concentrations of $\alpha_{S}$ CN would decrease and the relative concentrations of $\kappa$ - and $\beta$-CN would increase in both breeds. Also, $\mathrm{BB} / \mathrm{A}^{1} \mathrm{~A}^{2} / \mathrm{AB}$ has previously been shown to have a positive effect on rennet-induced gelation properties compared with $\mathrm{BB} / \mathrm{A}^{2} \mathrm{~A}^{2} / \mathrm{AA}$ in both $\mathrm{SR}$ and DH using the same sample set (Poulsen et al., 2013). However, further research is needed to more thoroughly investigate how detailed milk protein composition affects processing of different dairy products.

\section{CONCLUSIONS}

Significant differences exist in milk composition, protein profile, and frequencies of casein genotypes in 3 Scandinavian breeds (DH, SR, and DJ). Danish Holsteins and SR are quite similar regarding casein genotype frequencies, whereas the differences in casein genotype frequencies in DJ compared with the other 2 breeds are more pronounced. The same trend can be seen regarding the differences in milk composition and protein profile. Danish Holstein and SR cows with the common composite genotype $\mathrm{BB} / \mathrm{A}^{2} \mathrm{~A}^{2} / \mathrm{AA}$, with frequencies of 30 and $15 \%$, resulted in milk with lower relative concentrations of $\kappa$ - and $\beta-\mathrm{CN}$ and higher relative concentrations of $\alpha_{S^{-}} \mathrm{CN}$ than most of the other composite genotypes. The differences in relative protein concentration were not as pronounced between milk from cows with the most common composite genotype in $\mathrm{DJ}\left(\mathrm{BC} / \mathrm{A}^{2} \mathrm{~A}^{2} / \mathrm{AB}\right)$ and milk from cows with the other composite genotypes present at a frequency higher than $2.5 \%$. The present work suggest that a higher frequency of $\mathrm{BB} / \mathrm{A}^{1} \mathrm{~A}^{2} / \mathrm{AB}$, which is present in $8 \%$ of SR and $9 \%$ of $\mathrm{DH}$, together with a decrease in $\mathrm{BB} /$ $\mathrm{A}^{2} \mathrm{~A}^{2} / \mathrm{AA}$ frequency could have positive effects on $\mathrm{DH}$ and SR milk regarding, for example, cheese processability. Furthermore, this study shows that the effect of composite casein genotypes on protein profile should be considered in the national breeding programs to prevent changes in the detailed protein composition that could have negative effects on, for example, cheese production.

\section{ACKNOWLEDGMENTS}

The authors thank the Swedish Farmer's Foundation for Agricultural Research (SLF, Stockholm, Sweden), Arla Foods amba (Viby, Denmark), the Danish Cattle Federation (Aarhus, Denmark), the Danish Strategic Research Council (Copenhagen, Denmark), Aarhus University (Tjele, Denmark), and the Milk Levy Fund (Aarhus, Denmark) for financial support through the project "Milk genomics - Genetic influence on milk composition and technological properties," which is part of the Danish-Swedish Milk Genomics initiative. Also, the Danish sampling and analysis team of the Milk Genomics Initiative (Tjele, Denmark) are gratefully acknowledged for excellent technical assistance. A. J. Buitenhuis was supported by the project "Phenotypic and genetic markers for specific milk quality parameters" of the Milk Levy Fund (2011-2013).

\section{REFERENCES}

Åkerstedt, M., E. Wredle, V. Lam, and M. Johansson. 2012. Protein degradation in bovine milk caused by Streptococcus agalactiae. J. Dairy Res. 79:297-303. 
Anema, S. G. 2008. The whey proteins in milk: Thermal denaturation, physical interactions and effects on the functional properties of milk. Pages 239-281 in Milk Proteins: From Expression to Food. A. Thompson, M. Boland, and H. Singh, ed. Academic Press, San Diego, CA.

Auldist, M. J., K. A. Johnston, N. J. White, W. P. Fitzsimons, and M. J. Boland. 2004. A comparison of the composition, coagulation characteristics and cheesemaking capacity of milk from Friesian and Jersey dairy cows. J. Dairy Res. 71:51-57.

Bech, A. M., and K. R. Kristiansen. 1990. Milk protein polymorphism in Danish dairy cattle and the influence of genetic variants on milk yield. J. Dairy Res. 57:53-62.

Bobe, G., D. C. Beitz, A. E. Freeman, and G. L. Lindberg. 1999. Effect of milk protein genotypes on milk protein composition and its genetic parameter estimates. J. Dairy Sci. 82:2797-2804.

Bonfatti, V., G. Di Martino, A. Cecchinato, L. Degano, and P. Carnier. 2010a. Effects of $\beta$ - $\kappa$-casein (CSN2-CSN3) haplotypes, $\beta$-lactoglobulin (BLG) genotypes, and detailed protein composition on coagulation properties of individual milk of Simmental cows. J. Dairy Sci. 93:3809-3817.

Bonfatti, V., G. Di Martino, A. Cecchinato, D. Vicario, and P. Carnier. 2010b. Effects of $\beta$ - $\kappa$-casein (CSN2-CSN3) haplotypes, $\beta$-lactoglobulin (BLG) genotypes on milk production traits and detailed protein composition of individual milk of Simmental cows. J. Dairy Sci. 93:3797-3808.

Bovenhuis, H., J. A. M. Van Arendonk, and S. Korver. 1992. Associations between milk protein polymorphisms and milk production traits. J. Dairy Sci. 75:2549-2559.

Ehrmann, S., H. Bartenschlager, and H. Geldermann. 1997. Quantification of gene effects on single milk proteins in selected groups of dairy cows. J. Anim. Breed. Genet. 114:121-132.

Farrell, H. M., Jr., R. Jimenez-Flores, G. T. Bleck, E. M. Brown, J. E. Butler, L. K. Creamer, C. L. Hicks, C. M. Hollar, K. F. Ng-KwaiHang, and H. E. Swaisgood. 2004. Nomenclature of the proteins of cows' milk-Sixth revision. J. Dairy Sci. 87:1641-1674.

Frederiksen, P. D., K. K. Andersen, M. Hammershøj, H. D. Poulsen, J. Sørensen, M. Bakman, K. B. Qvist, and L. B. Larsen. 2011a. Composition and effect of blending of noncoagulating, poorly coagulating, and well-coagulating bovine milk from individual Danish Holstein cows. J. Dairy Sci. 94:4787-4799.

Frederiksen, P. D., M. Hammershøj, M. Bakman, P. N. Andersen, J. B. Andersen, K. B. Qvist, and L. B. Larsen. 2011b. Variations in coagulation properties of cheese milk from three Danish dairy breeds as determined by a new free oscillation rheometry-based method. Dairy Sci. \& Technol. 91:309-321.

Hallén, E., T. Allmere, J. Näslund, A. Andrén, and A. Lundén. 2007. Effect of genetic polymorphism of milk proteins on rheology of chymosin-induced milk gels. Int. Dairy J. 17:791-799.

Hallén, E., A. Wedholm, A. Andrén, and A. Lundén. 2008. Effect of $\beta$-casein, $\kappa$-casein and $\beta$-lactoglobulin genotypes on concentration of milk protein variants. J. Anim. Breed. Genet. 125:119-129.

Heck, J. M., A. Schennink, H. J. van Valenberg, H. Bovenhuis, M. H. Visker, J. A. van Arendonk, and A. C. van Hooijdonk. 2009a. Effects of milk protein variants on the protein composition of bovine milk. J. Dairy Sci. 92:1192-1202.

Heck, J. M., H. J. van Valenberg, J. Dijkstra, and A. C. van Hooijdonk. 2009b. Seasonal variation in the Dutch bovine raw milk composition. J. Dairy Sci. 92:4745-4755.

Heck, J. M. L., C. Olieman, A. Schennink, H. J. F. van Valenberg, M. H. P. W. Visker, R. C. R. Meuldijk, and A. C. M. van Hooijdonk. 2008. Estimation of variation in concentration, phosphorylation and genetic polymorphism of milk proteins using capillary zone electrophoresis. Int. Dairy J. 18:548-555.

Holland, J. W. 2008. Post-translational modifications of caseins. Pages 107-132 in Milk Proteins: From Expression to Food. A. Thompson, M. Boland, and H. Singh, ed. Academic Press, San Diego, CA.

Ikonen, T., M. Ojala, and O. Ruottinen. 1999. Associations between milk protein polymorphism and first lactation milk production traits in Finnish Ayrshire cows. J. Dairy Sci. 82:1026-1033.

Ikonen, T., M. Ojala, and E.-L. Syväoja. 1997. Effects of composite casein and $\beta$-lactoglobulin genotypes on renneting properties and composition of bovine milk by assuming an animal model. Agric. Food Sci. Finland 6:283-294.

Jann, O., G. Ceriotti, A. Caroli, and G. Erhardt. 2002. A new variant in exon VII of bovine $\beta$-casein gene (CSN2) and its distribution among European cattle breeds. J. Anim. Breed. Genet. 119:65-68.

Jensen, H. B., N. A. Poulsen, K. K. Andersen, M. Hammershøj, H. D. Poulsen, and L. B. Larsen. 2012. Distinct composition of bovine milk from Jersey and Holstein-Friesian cows with good, poor, or noncoagulation properties as reflected in protein genetic variants and isoforms. J. Dairy Sci. 95:6905-6917.

Jõudu, I., M. Henno, T. Kaart, T. Püssa, and O. Kärt. 2008. The effect of milk protein contents on the rennet coagulation properties of milk from individual dairy cows. Int. Dairy J. 18:964-967.

Lindmark-Månsson, H., R. Fondén, and H.-E. Pettersson. 2003. Composition of Swedish dairy milk. Int. Dairy J. 13:409-425.

Lucey, J. A. 2008. Milk protein gels. Pages 449-481 in Milk Proteins: From Expression to Food. A. Thompson, M. Boland, and H. Singh, ed. Academic Press, San Diego, CA.

Lundén, A., M. Nilsson, and L. Janson. 1997. Marked effect of $\beta$-lactoglobulin polymorphism on the ratio of casein to total protein in milk. J. Dairy Sci. 80:2996-3005.

Madsen, P., and J. Jensen. 2007. A user's guide to DMU. A package for analysing multivariate mixed models. Version 6 , release 4.7. Aarhus University, Tjele, Denmark.

McLean, D. M., E. R. B. Graham, R. W. Ponzoni, and H. A. McKenzie. 1984. Effects of milk protein genetic variants on milk yield and composition. J. Dairy Res. 51:531-546.

Miralles, B., M. Ramos, and L. Amigo. 2003. Influence of proteolysis of milk on the whey protein to total protein ratio as determined by capillary electrophoresis. J. Dairy Sci. 86:2813-2817.

Miralles, B., V. Rothbauer, M. A. Manso, L. Amigo, I. Krause, and M. Ramos. 2001. Improved method for the simultaneous determination of whey proteins, caseins and para- $\kappa$-casein in milk and dairy products by capillary electrophoresis. J. Chromatogr. A 915:225-230

Otte, J., M. Zakora, K. R. Kristiansen, and K. B. Qvist. 1997. Analysis of bovine caseins and primary hydrolysis products in cheese by capillary zone electrophoresis. Lait 77:241-257.

Poulsen, N. A., H. P. Bertelsen, H. B. Jensen, F. Gustavsson, M. Glantz, H. Lindmark Månsson, A. Andrén, M. Paulsson, C. Bendixen, A. J. Buitenhuis, and L. B. Larsen. 2013. The occurrence of noncoagulating milk and the association of bovine milk coagulation properties with genetic variants of the caseins in 3 Scandinavian dairy breeds. J. Dairy Sci. 96:4830-4842.

Poulsen, N. A., F. Gustavsson, M. Glantz, M. Paulsson, L. B. Larsen, and M. K. Larsen. 2012. The influence of feed and herd on fatty acid composition in 3 dairy breeds (Danish Holstein, Danish Jersey, and Swedish Red). J. Dairy Sci. 95:6362-6371.

Recio, I., M.-L. Pérez-Rodríguez, M. Ramos, and L. Amigo. 1997. Capillary electrophoretic analysis of genetic variants of milk proteins from different species. J. Chromatogr. A 768:47-56.

RYK (Foundation for Registration and Milk Recording). 2012. RYK annual report, 2012. RYK, Aarhus, Denmark.

Sørensen, L. K., M. Lund, and B. Juul. 2003. Accuracy of Fourier transform infrared spectrometry in determination of casein in dairy cows' milk. J. Dairy Res. 70:445-452.

Swedish Dairy Association. 2011. Cattle statistics. Swedish Dairy Association, Stockholm, Sweden.

Visker, M. H. P. W., B. W. Dibbits, S. M. Kinders, H. J. F. van Valenberg, J. A. M. van Arendonk, and H. Bovenhuis. 2011. Association of bovine $\beta$-casein protein variant I with milk production and milk protein composition. Anim. Genet. 42:212-218.

Walstra, P., J. T. M. Wouters, and T. J. Geurts. 2006. Dairy Science and Technology. 2nd ed. Taylor \& Francis, Boca Raton, FL.

Wedholm, A., E. Hallén, L. B. Larsen, H. Lindmark-Månsson, A. H. Karlsson, and T. Allmere. 2006. Comparison of milk protein composition in a Swedish and a Danish dairy herd using reversed phase HPLC. Acta Agric. Scand. A Anim. Sci. 56:8-15. 